\section{Creating a sense of community and space for subjectification in an online course on sustainability education during times of physical distancing}

\author{
Robbert Hesen
}

IVN - Dutch Institute for Nature Education and Sustainability, Amsterdam, The Netherlands

Arjen E.J. Wals

Department of Education and Learning Sciences, Wageningen University and Research, The Netherlands and Department of Science Education, Norwegian University of Life Sciences, As, Norway, and

Rebekah L. Tauritz

Department of Education and Learning Sciences, Wageningen University and Research, Wageningen, The Netherlands
Creating a

sense of community and space

Received 12 July 2021 Revised 28September 2021 16 December 2021 Accepted 5 January 2022

\begin{abstract}
Purpose - This study aims to demonstrate which course elements were responsible for community building, fostering subjectification and learning for being in an online course on environmental and sustainability education (ESE) during the COVID-19 pandemic and physical distancing.

Design/methodology/approach - The study investigates a graduate-level course on Environmental Education for Sustainable Living that due to COVID-19 had to be taught mainly online. A retrospective analysis was conducted when the facilitators reflected on why the course, against expectations, appeared to have affected so many students in such a meaningful and profound way as shown by their personal reflections and the course evaluation. Methodologically, this study can be described as explorative and interpretative, although it was complemented by a standardised empirical analytical end-of course evaluation.
\end{abstract}

Findings - Within the context of this study, sense of community is linked to and facilitated by the online learning environment and the educators' and students' roles throughout the course. This study found that interaction and inclusion can be augmented by a hybrid educational design and supported by the mutual efforts of educators and students. Reflective tasks and discussions most prominently evoked subjectification. The encouragement of students to see themselves as central subjects and the inclusion of creative tasks supported both personal exploration and sense of community.

Originality/value - This study provides educational institutions teaching online with valuable information regarding course elements that foster subjectification and create a sense of community. This is

(C) Robbert Hesen, Arjen E.J. Wals and Rebekah L. Tauritz. Published by Emerald Publishing Limited. This article is published under the Creative Commons Attribution (CC BY 4.0) licence. Anyone may reproduce, distribute, translate and create derivative works of this article (for both commercial and non-commercial purposes), subject to full attribution to the original publication and authors. The full terms of this licence may be seen at http://creativecommons.org/licences/by/4.0/ legalcode

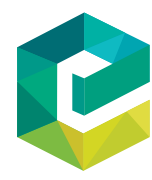

International Journal of Sustainability in Higher Education Vol. 23 No. 8,2022 pp. $85-104$ 1467-6370 DOI 10.1108/IJSHE-07-2021-0270 
IJSHE 23,8

particularly of interest for the design of online ESE emphasising learning for being and more relational approaches towards teaching and learning.

Keywords Sense of community, Online learning, Subjectification, COVID-19, Hybrid learning, Environmental and sustainability education

Paper type Case study

A course that affects the self. Very different from what I am used to in academics. Neither based on technology nor on theory, but rather focused on one's personal development - Int.11[1]

\section{Introduction}

Over the past year - since the COVID-19 pandemic's beginning in early 2020 - education has changed significantly. An article on the World Economic Forum was headed: "The COVID-19 pandemic has changed education forever" (World Economic Forum, 2020). The pandemic prompted disruption and nationwide closures of educational institutions to prevent the spread of the virus. This affected more than a billion learners (UNESCO, 2020). Educational institutions provided online education in efforts to mitigate the immediate impacts of the pandemic. In response, the proliferation of virtual environments soared to new heights, as universities sought to transition to online teaching. Video conferencing platforms such as Skype, Zoom, MS-Teams and Google Hangouts, along with learning management systems, were widely used (World Economic Forum, 2020). As classroom environments rapidly became virtual ones, the question arose as to how this transition would impact education. In line with this trend, research concerning online environments and learning experiences gained relevance and importance. For educational programs seeking to stimulate other forms of learning (e.g. art-based, place-based and embodied learning), the necessitated transition to online learning could hinder the incorporation of these forms of learning.

These other forms of learning have shown to be quite crucial for sustainability-oriented higher education which seeks to foster deeper connections with and between people and planet by also paying attention to social emotional and embodied forms of learning (Eernstman and Wals, 2013). Education in the context of sustainable development is often seen as a means to develop sustainability competencies (Brundiers et al., 2021). In addition to this qualification task, Biesta (2010) points at two other key functions of education: socialisation and subjectification. Socialisation refers to "the (re)presentation of cultures, traditions, and practices" (Biesta, 2020, p. 92), which in the sustainability context include norms and values that correspond with awareness as well as acting in the interest of the self, others and the planet (Van der Meer and Wals, 2017), whereas subjectification refers to an individual's right and freedom to become who he or she wants to be in the world without impeding on the possibilities for others to do so as well. In the context of sustainability, subjectification is bound by the ecological boundaries within this becoming occurs. Although qualification might still be possible in online learning, this might be more difficult for socialisation and subjectification. How then can sustainability-oriented higher education utilise online education while still allowing socialisation and subjectification to take place (Ellis et al., 2020)?

This research arose when a course at Wageningen University, ELS-31806 Environmental Education and Learning for Sustainability[2], had to be converted from an "offline" course into an online. Its original content and setup enabled students to systematically discuss and explore important concerns in the development of learning-based interventions or activities using carefully chosen instrumental and/or emancipatory approaches to actively engage 
people in a sustainability challenge (Wals et al., 2008). Traditionally, ELS-31806 was a wellappreciated and highly valued course due to its experiential and hands-on approach. Due to COVID-19, the 2020 version of the course required a redesign using a less experiential online format mediated by the video conferencing platform Zoom for interaction and by Brightspace for course structure and organisation. This somewhat ad-hoc and sudden departure from the traditional successful format lowered the instructors' expectations about the course and its ability to create a vibrant learning community. Yet, contrary to pre-course expectations, "something" occurred during the four weeks of online education that both students and staff considered to be especially meaningful. Students and teachers, all part of a Life Sciences Engineering University which does not have an Arts and Humanities faculty, increasingly opened up, sharing inner thoughts, reflecting on personal values and sharing heartfelt emotions concerning environmental issues with each other. Singer-songwriters, poets, dancers and yoga teachers emerged as the students, explored the sustainability themes of the course. People who were physically distanced, who never actually met in "real life", unexpectedly and collectively built a community based on the grounds of trust in which deep and meaningful reflection occurred. Seemingly the course's unconventional character contributed to this new ambience as students were, through various planned activities, provided with the opportunity to explore their emotions and values regarding sustainability issues and challenged to share these with others. This was exemplified in activities designed to reconnect with nature such as the "sit-spot" - students experiencing their surroundings in favourite natural places close-to-home, and "lines of the hand" evoking students' imagination to recall imaginary landscapes from memory that gradually helped students to come out of their shells. The course's final online session was remarkable in that, after the final words announcing the official end of the course had been spoken, none of the nearly 70 students appeared to want to leave the Zoom meeting; nobody seemed to want to step out of the community that had been created. These individual and collective concurrences made us realise something special had happened.

Our impressions were confirmed several weeks later, by way of Wageningen UR's student evaluation system: PaCE. In previous years, the average overall satisfaction score across all courses at Wageningen UR that took place online during that semester was 3.8 on a scale of 1 to 5 (Wageningen University and Research, 2020). Students in this course were satisfied, rating the course 4.4 on average; nearly as much as the 4.7 average the off-line versions received in previous years. This high score provoked us to dig deeper into how and why the students were affected by the course and what elements of the course affected them most. We were intrigued by the question of how this online edition evoked "something" similar to its offline counterpart.

The academic debate about the role of community in online educational environments revolves mainly around how students' acquisition of knowledge can be enhanced (Rovai, $2002 \mathrm{~b})$. While these environments are praised for increasing access to and cost-effectiveness in education, disadvantages of these environments are highlighted through high attrition rates (Perna et al., 2014) and low learning engagement (Hu and Hui, 2012). Rovai (2002a) ascribes these high dropout rates in online courses to physical separation which in turn may lead to isolation (Besser and Donahue, 1996) and disconnection (Kerka, 1996) . Countering this physical disconnection, virtual communities aim to keep users engaged, as do "physical" communities, by stimulating a sense of belonging, trust, familiarity and perceived similarity (Zhao et al., 2012). Rovai (2002a) shows that courses with a strong sense of community are characterised by "good teacher characteristics, cooperation and strong student connections, consistent flow of information between participants, a change in personal perspective, quality learning, students' perceived learning, and overall satisfaction" 
IJSHE 23,8

\section{8}

(as cited in Balboni et al., 2018, p. 319). Building upon the work of scholars such as Rovai (2002a) and Liu et al. (2007) who studied the (positive) relation between sense of community and learning environments, our central research question here is: What are key elements of an online sustainability education course that foster subjectification, socialisation and a sense of community?

\section{Theoretical underpinnings}

Socialisation and sense of community

McMillan (1996) describes an individual's feeling of a sense of community as:

[... ] a spirit of belonging together, a feeling that there is an authority structure that can be trusted, an awareness that trade, and mutual benefit resulting from being together, and a spirit that comes from shared experiences that are preserved as art (McMillan, 1996, p. 315).

These concepts are associated with socialisation and being or becoming part of a community. Their relevance here lies in the conceptualisation of community building through a safe learning environment in which both students and teachers play an important role.

Based on these concepts Rovai (2002a) devised four components, configured to suit classroom communities: spirit, trust, interaction and learning. Spirit and trust are related to Lange's (2009) learning sanctuary which refers to a safe place, built collectively to protect its members from outside (social) forces. Regarding interaction, Hare and Davies (1994) distinguish two interactional categories: task-driven interaction and socioemotional interaction. Emphasising the relationships and interactions between students, socioemotional interaction enables well-being and supports developing friendships, whereas task-driven interaction focuses on learning (Rovai, 2002a). Scholars agree that increased levels of interaction are essential to participants' online learning experience (Graham and Scarborough, 2001), high levels of course satisfaction (Jung et al., 2002) and in creating a sense of community (Rovai, 2002a; Liu et al., 2007). According to Liu and Schwen (2008), lack of in-depth dialogue impedes a sense of community. Rovai's (2002a) final component, learning, relates to the student's recognition of a common purpose among group members. Similarly, Liu et al.'s (2007) study demonstrates the importance of group work in building a learning community "by encouraging group learning experiences through a shared task goal” (Liu et al., 2007, p. 19).

Shea et al. (2002) argue that from a student's perspective a sense of community is inherently connected to design, facilitation and assessment, elements that highlight the teacher's role. From a design perspective, Weidlich and Bastiaens (2019) argue that learning environments can be created embodying greater or lesser degrees of social interaction. They suggest that social affordances are essential to online learning environments, saying "just like a town square affords meeting and interacting with people in the physical space, online environments can also afford social behavior" (Weidlich and Bastiaens, 2019, p. 2). In Berge's (1995) four dimensions of online instructor roles, the social category emphasizes the creation of friendly and social environments that promote learning. Liu et al. (2007) state that online instructors require nurturing skills to create such environments. This in turn can be associated with facilitation (Shea et al., 2002) and Berge's dimensions regarding instructor's pedagogical, managerial and technical roles in online courses. With regard to pedagogical principles, various sustainability education experts highlight the exemplary role of the teacher who "can play an important role by explicitly and openly making his or her values, attitude and pedagogical principles part of the learning process, but also by showing congruent behaviour" (Van der Meer and Wals, 2017, p. 19). 
Brown (2001) cautions that a sense of community will only unfold if and when the participants want it. She classifies three levels of community experience in distance learning: making online friends, sensation of online community inclusion and appreciation of companionship. Rice-Lively (1994) claims that even basic duties such as partaking in decision-making are important in community building. Emphasising the role of the student, these scholars (Rice-Lively, 1994; Brown, 2001) argue that a sense of community is reliant on student participation. In accordance with Rovai's (2002a) other dimensions of classroom community, Liu et al. (2007) state "a deep trust or spirit of community lies in the commitment and mutual engagement of community members" (p. 21).

Based on our review of literature, sense of community in education arises from a safe learning environment and from the way teachers and students generate such an environment together. Comparably, Lange (2009) puts it well when stating that education should provide:

[...] a protective sanctuary for a deep encounter with self (mind, spirit, and body), social relationships, habits of thinking and living, and the conjoined individual and social myths that constrain human freedom and justice (p. 197).

\section{Subjectification}

Lange's statement highlights the function of education in navigating the pedagogies of critique and hope (p. 197). In relation to environmental and sustainability education (ESE), O'Sullivan (1999) argues that this pedagogical confrontation magnifies:

[...] the sense of self, from seeing oneself as separate and autonomous to seeing one's embeddedness in a web of living relations, both human and nonhuman, constitutive of an ecological consciousness (as cited in Lange, 2009, p. 197).

Biesta (2010) argues that subjectification is "a way to express agency and "independence" from the orders of a community" (as cited by Hasslöf and Malmberg, 2015, p. 241), or the "freedom to exist as the subject of my own life, not as the object of what other people want from me" (Biesta, 2020, p. 93). Education should invite students to take ownership of their own learning process (Hasslöf and Malmberg, 2015). In contrast to the socialisation function, subjectification in education aims at individuals becoming more autonomous and independent in their thinking and acting rather than adapting, as individuals, to the group's collective identity (Biesta, 2010). However, truly autonomous subjects do not exist (Kipnis, 2011), as our actions are always dependent on others (Loftus and Madden, 2020). Biesta's conception of subjectification centres around the: "idea of an individual coming into being and the uniqueness of that individual" (as cited in Loftus and Madden, 2020, p. 460). According to Loftus and Madden (2020), "coming into being and "uniqueness" cannot be taught, but rather require the teacher to create the conditions for subjectification in the classroom. Loftus and Madden (2020) argue that education can contribute to the student's "coming into being" and exploring their "uniqueness" by conferring responsibility for others, exposure to differences, and promoting the student's problem-solving capacities (p. 460). Or as stated by Hasslöf and Malmberg (2015):

$[\ldots]$ it is a matter of arranging education in a way that gives space to challenge existing orders, to get new perspectives on an issue and to leave possibilities for the students to explore their own relation to existing discourses (p. 241).

Sustainability-oriented higher education stimulates critical thinking and reflection to challenge the discourse surrounding sustainability challenges and to promote alternatives ways of being and doing (Hasslöf and Malmberg, 2015). 
IJSHE 23,8

Subjectification in education links community building with sustainability issues through exploration of the self within the boundaries of a safe learning environment. Here critical thinking is advocated to challenge existing sustainability discourses. Amidst this pedagogical confrontation of critique and hope in sustainability discourses, ELS-31806 attempts to ultimately create conditions which promote the student's "coming into being".

\section{Methodology and methods}

Environmental and sustainability education-31806 context

The course enabled students to actively engage with environmental and sustainability issues through a hybrid mix of activities. Course content centred around the development of environmental and sustainability interests, concerns, and competences as well as the transition to sustainable living and ecological consciousness using forms of education and learning. Students were familiarised with the field of sustainability education in week One, place-based learning and the use of art in education in week Two, and empowerment and societal transformation in sustainability education in week Three. The Fourth and final week, furnished perspectives alternative to the ones students learned in the previous weeks. Interactive plenary lectures were interspersed with individual activities (outside the online environment), including a personal introduction video and a "sustainability walk"[3], which were discussed later on in class. All online sessions employed the "Zoom" virtual learning environment. Besides the everyday content, students participated in a group assignment, an online discussion assignment, and a reflection assignment. The group assignment involved designing a plan of action to address a sustainability challenge within a context of their own choice. An online discussion arena was created on "Brightspace" to engage the students more deeply in the course literature. In weeks two and four students were asked to compose a reflection in the form of a personal course diary. These creative products served as artistic demonstration of what was learned and how this affected the students.

\section{Process}

Underlying questions unfolded during the course and the weeks thereafter when the team reflected on why the course "reached" so many students in such a meaningful and profound way. The research, as such was both emergent, in the sense of not well-planned and articulated in advance. It was also iterative in the sense that questions informing conversations with students and the analysis of their course reflections then led to new questions. Methodologically this study can be described as retrospective, explorative and interpretative, although a standardised empirical analytical end-of course evaluation was also used to gauge students' assessment of the course relative to others taught at Wageningen University. The explorative nature lies in the fact that the research did not try to test a hypothesis or to generate results that could be generalized or directly transferred to another context. Instead, it sought to create a deeper understanding of students' experiences and how they were affected by the online course. The study searched for possible explanations for these experiences and "affects". Affect refers here to a students' affective state, i.e. how this course affected their moods and emotions (Linnenbrink, 2006). The interpretative nature lies in the fact that students spoke for themselves through their unique expressions in writing, dance, poetry and drawings and during interactive lectures and semi-open conversations with researchers around emergent themes.

As all the data arose from a single course, the research can best be considered a case study. The field setting was an online course within the Education and Learning Sciences chair group at Wageningen UR in The Netherlands. Students were requested to actively engage in some reflective tasks, including the writing of personal course diaries. Even 
though the students were all part of a Life Sciences Engineering University that traditionally tends to ignore arts-based approaches, students could also opt to use music, rap, spoken word, poetry and visual arts to express how the course affected them. Many opted for such an alternative form of expression. A total of 69 bachelor and master students completed a midterm and final personal course diary, accounting for $20 \%$ of the student's grade. These reflective assignments provided important insight into the students' affective states thereby enriching our understanding of affective learning outcomes. The final personal course diaries were evaluated and analysed for this research to gain a better understanding regarding the sense of community among students and how this online course fostered subjectification. A thematic analysis (Braun and Clarke, 2006) sought patterns within these reflective student assignments. To arrive at an even more thorough description of experiences and affects, fifteen students (randomly assigned) were interviewed employing semi-structured questionnaires. The online interviews were kept short in acknowledgement of students' screen-time overload. Typically interviews lasted between about $15 \mathrm{~min}$ and centred on the following topics: introductory chat; overall impression of the course; advantages/limitations of online lecturing; and expressiveness of learning components. The PaCE analysis, composed of 42 matrix questions (i.e. Likert scale questions), merely confirmed our impressions and was excluded from further analysis.

\section{Data analysis}

Student reflections. All qualitative data were inductively coded employing data analysis software ATLAS.ti 8 and analysed using a theoretical thematic analysis approach (Braun and Clarke, 2006). To enhance the finding's credibility, this study used methodological source triangulation, i.e. using student reflection assignments, student interviews and the $\mathrm{PaCE}$ evaluation outcomes. The latter was only used to confirm our initial impressions during the course.

Selection and interpretations of the student reflection assignments took place in three phases based on Braun and Clarke's (2006)[4] thematic analysis approach. A total of 69 student reflections assignments were combined in one text document and uploaded to ATLAS.ti 8. Phase one of the data analysis process comprised the main researcher's familiarisation with the data. Within ATLAS.ti 8, the following two automatised steps were taken:

(1) An initial frequency-based categorisation of words through ATLAS.ti's word cloud. Commonly used words, such as "breakout room" (a function in Zoom to split students in small groups) and "lecture", were selected by the ATLAS.ti's Auto Coding tool.

(2) Subsequently the Auto Coding tool generated quotations (full sentences that included the frequently used words). These quotations were then organised by the researcher.

These computerised steps simplified selection, requiring, however, verification by the researcher as quotations could be labelled incorrectly or prove to be irrelevant. After verification, the quotations were read and re-read to achieve a better understanding concerning the auto selection leading to the finalisation of phase one. Phase two, the generation of initial codes, combined the frequency-based "codes" of phase one with additional features highlighted by the researcher but not dealt with by the standardised auto coding tool. Since the initial approach was semantic (Braun and Clarke, 2006) and the ATLAS.ti's Auto Coding tool cannot draw meaning from text, phase two required a non-automated analysis by the researcher. Giving context and meaning to the data 
IJSHE

23,8

92

simultaneously illuminated potential themes. At the end of the second phase the entire data set was coded using 11 codes. Figure 1 presents an example of a data extract that was coded using three codes. The third phase, centred on the formulation of themes, compared the 11 codes on coverage, cohesion and commonalities to fit the data, and reorganised them into the broader level: themes. The 11 codes were sorted into possible themes and all coded data extracts were processed within these themes. For instance, the coded data extract in Figure 1 was collated under the identified theme: "community".

Regarding the more artistic reflection assignments (Figures 2 and 3), the analytical focus lay with the word-based information supplied by the students to stay as close as possible to the students' artful expressions to enhance analytical trustworthiness.

\section{Interviews}

Complementary to the reflection assignments, short interviews were conducted with sixteen random participating students. These students answered semi-structured interview questions about their overall impression of the course as well as specific activities. They were also asked to recall their feelings and emotional responses during the course. The interviews provided the opportunity to probe more deeply and understand the students' sense of community and the process of subjectification. Contrary to the reflection analysis (Figure 4), the interview analysis initially used "people" and "participation" as codes in addition to the reflection codes. However, after revaluation, these were merged with "community" and "course elements". "Learning" eventually fused with the equal overarching main theme: "learning environment".

The interviews were used to study the students' overall experience of the online character of the course and the various activities throughout the four-week programme. The interview dataset showed sufficient similarities which led to the same final thematic map (Figure 5). The Zoom-mediated interviews of fourteen of the fifteen students were video recorded through Zoom's recording option. This was done for the sake of maintaining the flow during the interviews. One student did not provide consent for the recordings and therefore scratch notes were made during the interview. The recorded interviews were transcribed in the days following the interviews and the scratch notes were translated into field notes.

In the analysis the codes applied to the raw data (Figure 1) formed the initial main- and sub-themes (Figure 4). The sub-themes that formed overarching relations with multiple main themes were placed side by side with the dataset and checked to see if they would form main themes. Here the analysis surpassed its original semantic approach and started to examine beyond what was explicitly said or written (Braun and Clarke (2006). For instance, the word "inclusion", not used by any student, nonetheless incorporates one of the essences of the data set. In this way more interpretation was given to data extracts, codes and the defined themes. Some sub-themes were nominated as main themes for the entire data set, while several main themes could be merged. Eventually all potential themes were separated and rearranged into another thematic map (Figure 5). Notably, themes were retitled to capture the essence of each individual theme in the initial thematic map. "Learning

Figure 1.

Data extract, with initial codes applied in ATLAS.ti
When thinking about reflecting on the last two weeks of this course, the most interesting lesson I learned is that the dynamic in a group is more important for education than I first had thought.| $\triangle$ Community Course elements $\Delta$ Learning 


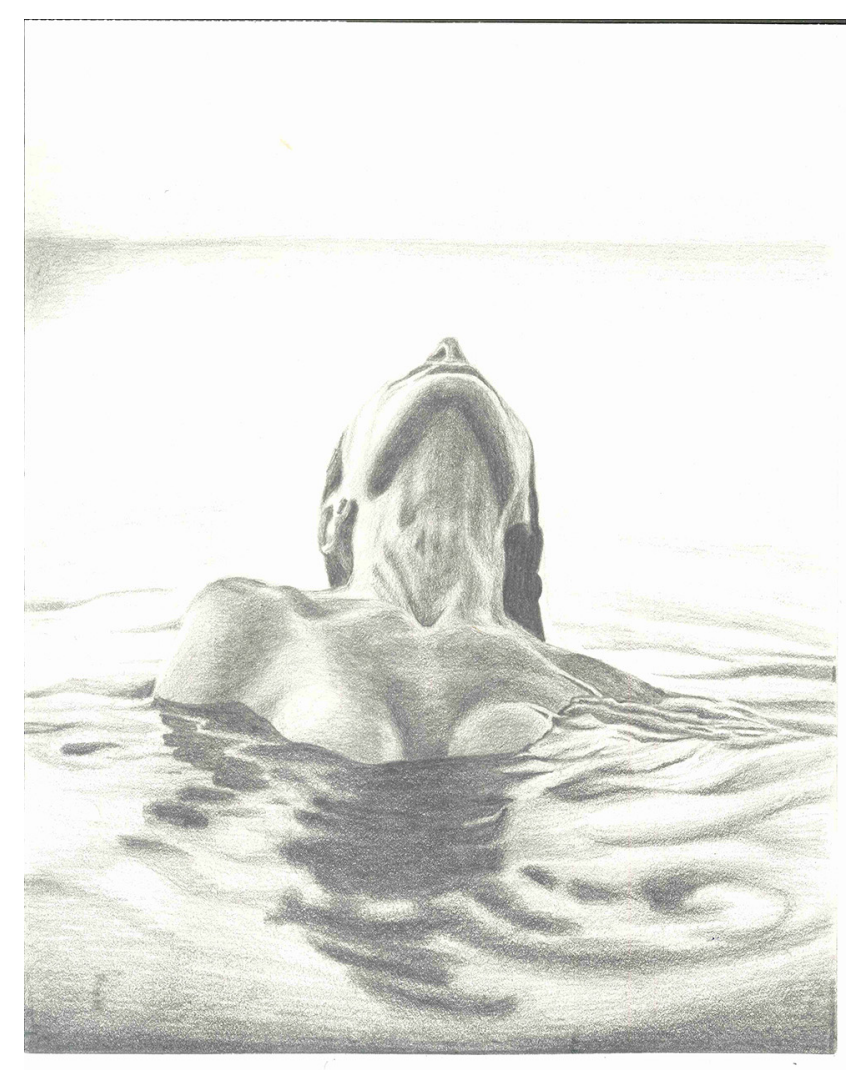

\section{Creating a sense of community and space}

Figure 2.

Handmade painting by a student on

"Empowerment-a rising sensation that liberates you from 'sinking' into negativity" - Ref.7

environment" became the main theme including all the initial seven themes, albeit nonhierarchical as each theme is labelled equally important.

\section{Findings}

In this section we present empirical support for a sense of community and subjectification among students having been triggered by certain elements of the online course. Based on the data analysis we were able to connect certain characteristics or qualities of the learning environment that enabled a sense of community at the collective level and subjectification at the individual level (Figure 6).

\section{Fostering a sense of community and socialisation}

A safe learning environment. The learning environment seemed to be a harmonious composition of inclusion, interaction and course elements. Interaction and inclusion were significant initiators and contributors to the course's "atmosphere". Inclusion empowered and motivated students to reflect, feel and share their emotions authentically. Interaction 
IJSHE

23,8

94

\section{Figure 3.}

"Sickness of the West" portrayed in a student's reflection Ref. 46 created by Linda Dobson (Reprinted with permission)
Figure 4.

Initial thematic map (seven themes) with sub-themes
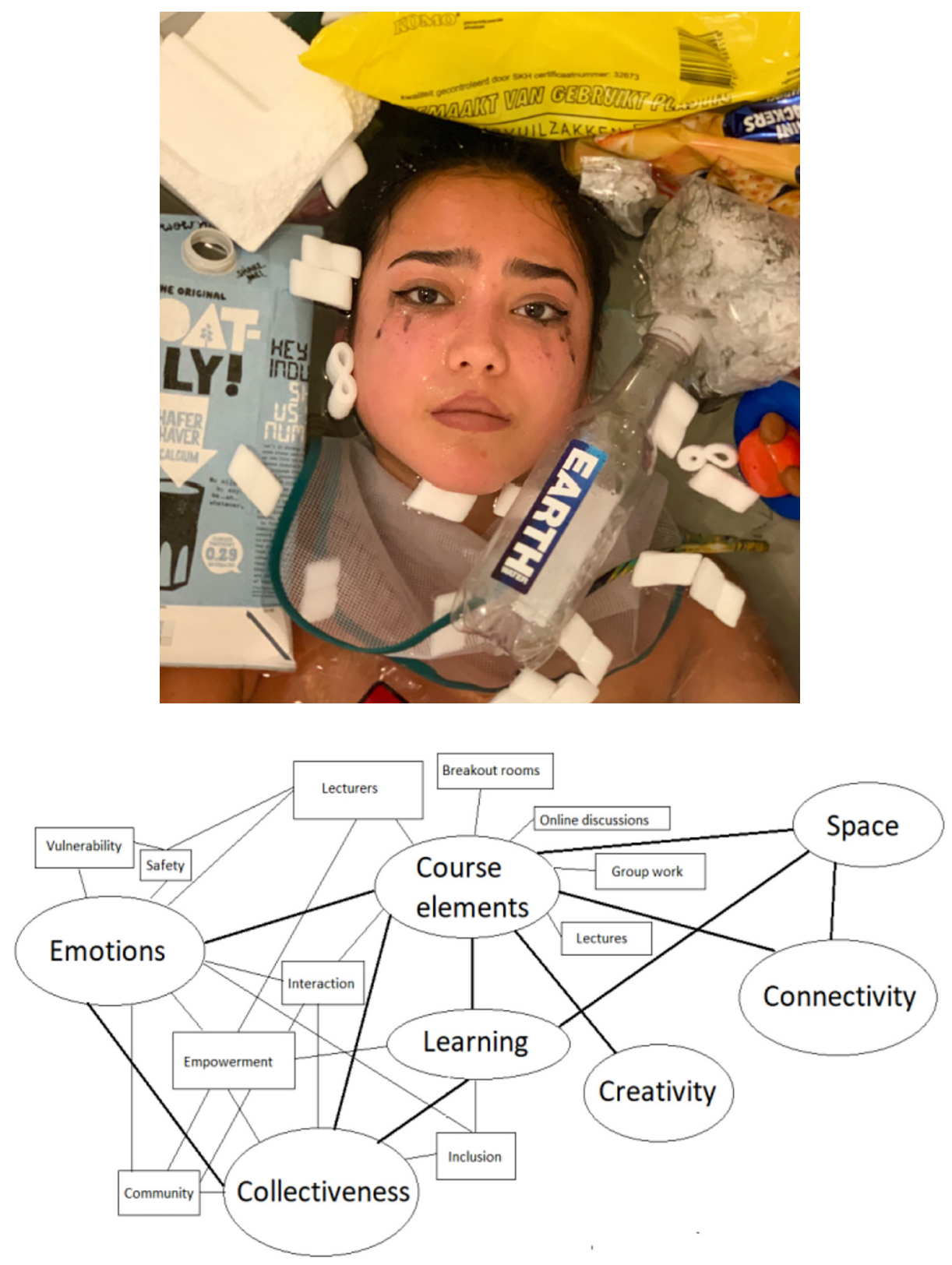

elicited meaningful conversations by actively bringing students, and educators, together. Course elements is used here as an umbrella term signifying everything related to the course, both static and dynamic elements. The static element is embedded in the course design, i.e. the structure that is created prior to the course. Lectures, online discussions and the group 
design assignment exemplify static course elements. The dynamic elements, requiring the educator's trust that valuable learning takes place when students are given agency, create space for emergence and surprise. Unplanned activities throughout the course invited interaction and inclusion.

One of the key characteristics of the learning environment was its auxiliary capacity to facilitate inclusive learning. Students emphasised that learning together contributed to the collective as well as the student's individual learning process. In a learning environment welcoming inclusive learning, students seemingly began to experience a collectively generated sense of belonging. Most of the students, for instance, linked their positive learning experiences to aspects like "community". Words like "students" and "people" were interchangeably combined with "group", "together" and "each other". Deconstructing

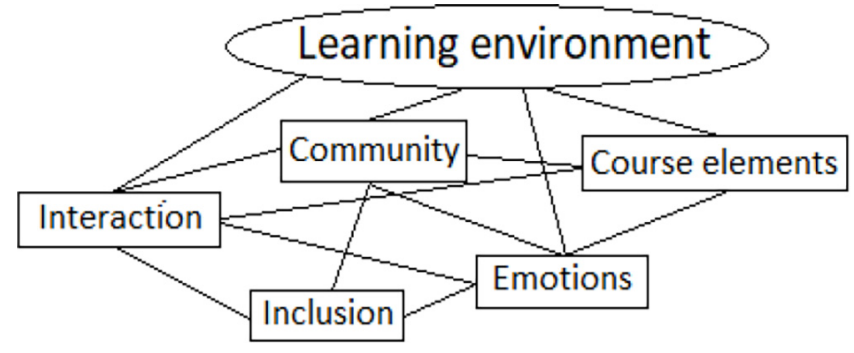

Figure 5. Final thematic map

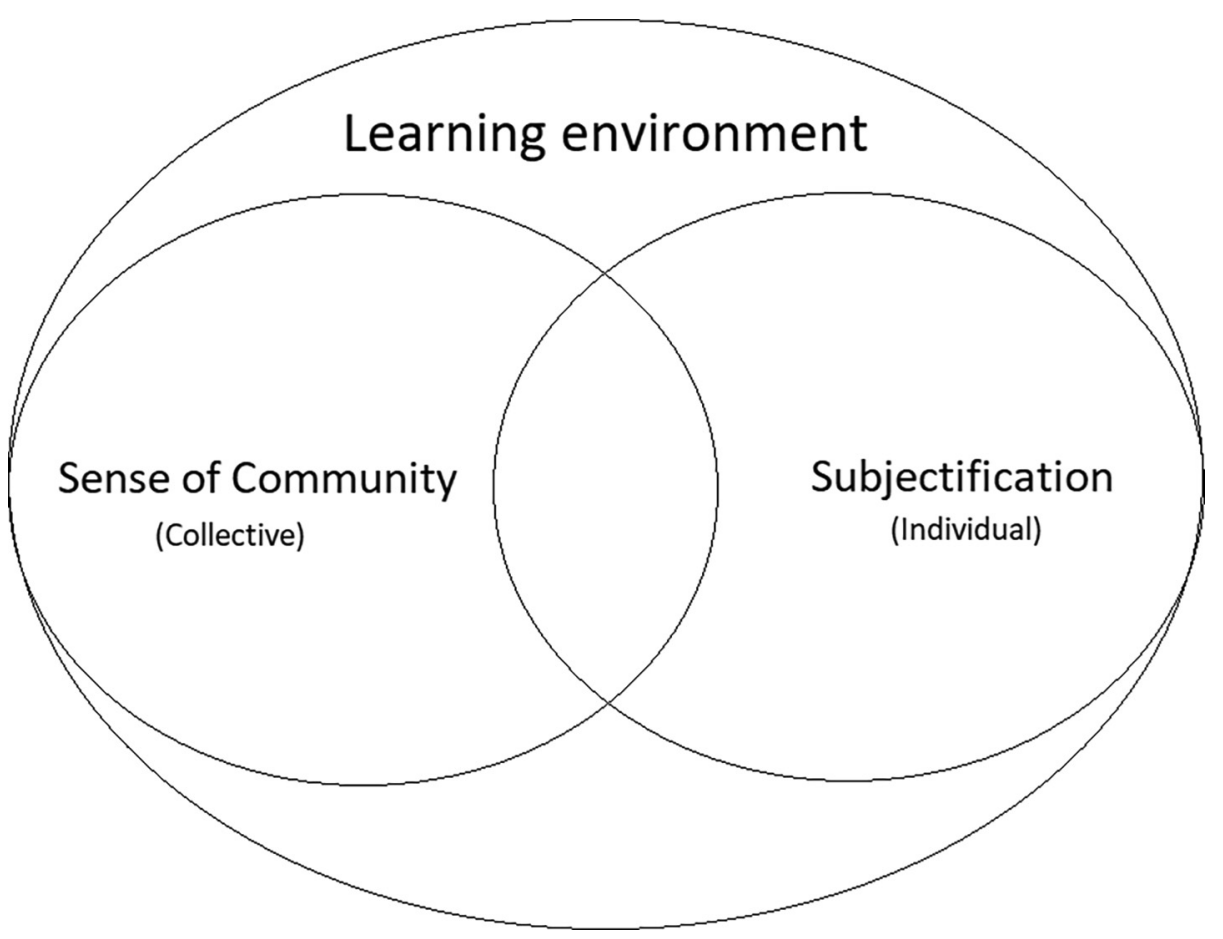

Figure 6. Final analytic map 
IJSHE 23,8

these patterns even further, the analysis reveals "we" and "us" as expressions symbolising "togetherness" and "connection". One student said:

I did feel that we as a class made a transition together even though we never saw each other in real life (Ref.5).

Another student noted:

The effort to create a vivid group dynamic and the unique circumstances we experienced due to the coronavirus, made this course very special and increased the learning curve, at least for me (Ref.10).

Although the respondents confirmed that COVID-19 and physical distancing created a need for belonging, and these factors can be viewed as catalysts for the sense of community that emerged, the respondents also expressed that the course setting itself was instrumental in community building.

Another key characteristic of the learning environment, and closely tied to inclusion, was interaction. Most students even pointed out that the online learning environment of this course increased interaction compared to traditional (interactive) courses, with students triggered to interact even more. Students mentioned the personal introduction videos, uploaded at the beginning of the course [online uploads], among other course activities (e.g. the sustainability walks) incorporated at the beginning of the course as crucial elements in encouraging peer engagement. One student related:

Because we had this connection built in the class, where we made videos, watched each other introductions and things like that we all were a bit more friendly with each other. I have not experienced that in other online groupwork. Something that was cultivated in the beginning really made a difference in that aspect (Int.15).

Another student's reflection personified this rather well:

The interactive components of the course, especially the discussion forum and the break-out rooms, gradually cracked my shell. Sharing and discussing my personal views, values, and feelings with other students, I found both reassuring and inspiring (Ref.64).

Referring to interaction-based components as part of the course, this student emphasised that sharing and discussing personal information were prominent factors in fostering a sense of community.

ELS-31806's design inevitably influenced the learning environment. Students felt challenged by various course elements to learn together and to share these experiences afterwards with other students. A course element that was mentioned frequently were the breakout rooms [randomised group splitting in online lectures on Zoom] stimulating students to actively engage in smaller groups of four-five students. One student said:

I liked the breakout rooms which helped to engage a lot of personal values into the course content. So, we were talking about our own experiences. And through that I felt emotionally connect to the content that we were learning about (Int.10).

When asked about these breakout rooms being incubators for deeper forms of engagement with the course content, this student continued:

I am even in contact with some fellow students I met during the breakout rooms. We shared information and I am still talking to them today [two weeks after the course finished]. I feel that the breakout rooms really helped making connections with people and still lasting till now (Int.10). 
In particular, course elements asking students to share personal values, stories etc., contributed to a sense of community that was seemingly further stimulated by working in smaller groups. Students expressed that due to smaller group presence in the breakout rooms, approximately four-five students compared to sixty-nine students in plenary activities, interactivity was promoted and inclusion incentivised.

Seemingly one of the most important characteristics of the learning environment fostering a sense of community and contributing to socialisation, was safety. Students highlighted that the learning environment invited them to open up towards each other but that mutual trust and feelings of safety were leading in the creation of "community". One student's reflection personified this rather well:

The empowerment exercise [assignment during lecture] required us to lower our fences and create bridges between each other. I believe that vulnerability can be a strong characteristic of community building and sustainable education. [.. .] During the session, I felt empowered by my peers' stories, my own story and the reaction of my peers on my story. In other words, I felt like I could conquer the world and I felt like I just bonded with some strangers online, all in one morning. We had a special moment of vulnerability. This moment of empowerment can raise a classroom to new levels and create a beautiful bond and atmosphere, which is necessary for creative dynamics in a classroom Ref.36.

These feelings of safety amongst peers "lowered their fences" and made them vulnerable and empowered, welcoming a seemingly increased sense of community. The creative exchanges between students were particularly mentioned as catalytic. Similarly, another student's reflection stated:

This course has taught me that the opportunity to talk to people you don't know can also be created in alternative ways: writing poetry (first in my mother tongue to loosen up and then in English), working in breakout rooms that are always different, exposing one's thoughts through a colour so that I can do it with peace of mind. I felt comfortable (Ref.65).

The fact that "I felt comfortable" was typed in bold by the student accentuates the importance of feeling at ease among peers within a (online) community. Some students even mentioned that the comfortability of working from home made them feel safe to speak their mind.

Nurturing role of educators and students. Students also expressed the importance of teachers as catalysts for the "right" conditions within the virtual classroom. By being authentic and open to feedback, educators created a safe learning environment in which students felt supported and in which students could have open conversations with one another as well as with their teachers. One student stated (translated from Dutch):

By being open to feedback and very clearly offering the students a learning environment - a free space in which you can experiment, learn, collaborate and ask questions - is very important for students to feel safe and to use this - Int.11.

The same student continued in this translated message:

It is probably a general opening up by the teachers. And also, the platform that [the teacher] creates: a kind of open conversation with the students. So, because this message, the course being characterised like this, is spread honestly and openly also opens the floor for students to participate in it (Int.11)

alluding to educators creating a safe learning environment in which students feel supported and encouraged to actively engage in the course. 
IJSHE 23,8
Students underlined the student-educator relationship, and this course being less conventional regarding it (i.e. closer relations between student and teacher), as important to community building. Students mentioned that the teachers were being attentive to the students' needs and feelings. This nurturing role seemingly created an environment for students in which they felt welcome and valued. One student said:

I really liked that you [the educators] considered the humans behind the students! In some courses I kind of feel like a 'machine' that has to perform and in this course, I could reflect and you actually listened to our needs and feelings (Ref.22).

Another student's reflection stated:

teachers should be those who help students to learn how to manage their emotions, so that students are not scared in such a way as to remain "frozen". [... . You [the educators] have been these kind of teachers and this course has made me feel part of something common (Ref.65).

Although this indicates that educators were important in creating a learning environment that fosters a sense of community, the analysis found that students were also important in creating an atmosphere that invites peer engagement and bonding. One student concluded a reflection with: "My best regards to the lecturers and students who built this course atmosphere into a more satisfied one" (Ref.49). This student portrayed the course atmosphere as a co-creative process between peer students and teachers. In this example 'satisfaction' indicates both the student's positive feeling towards the course atmosphere and the classroom community.

\section{Fostering subjectification}

At the individual level, students communicated that the learning environment along with certain course activities made them self-reflective and brought about deeper levels of learning. By facilitating activities concerning sustainable development discourse and what kind of individuals they want to be, students were stimulated to connect to themselves, their intuition and creativity. Creative and reflective tasks fostered this selfconnection and were seemingly important characteristics in fostering subjectification. Activities where students were asked to express themselves, like the personal course diaries and other individual performances, were especially catalytic for individual development. Students also talked about the open way in which these assignments were to be interpreted by the students. One student reflection stated:

I really felt that the course taught me something more deeply. [. . .] A course that guided me into challenging my thinking, into new perspectives and in deeply understanding different perspectives on how to educate (Ref. 5).

One interviewee said:

I think the assignments leave a lot of room for personal interpretation. And especially that you can think about it in your own way. For example, with the reflection assignment I found it very valuable that I could express what came in in my own way (Int.9).

Another important characteristic was the emancipatory element of the course, specifically students becoming part of the narrative through participation, co-creating the outcomes of certain activities. Students told that these individual contributions, sharing stories, personal value and feelings, inspired and empowered them as individuals. One student said:

Overall, this course gave me a lot of inspiration (for now and for my future) and self-confidence. I think the emancipatory parts of the course played a large role in this (Ref.69). 
Another student reflection described this rather well:

During the lecture [Empowerment and capacity-building for making change], we had to think of an experience in which we felt empowered. This made me realize that empowerment is an experience that can largely increase people's sense of agency, which I think is crucial to bring about change through environmental education. Also, I learned from this lecture that education cannot empower people, but that it can create the conditions that are required for people to empower themselves - Ref.3.

Creating a sense of community and space

Besides suggesting that the lecture and its content stimulated various forms of learning as well as empowerment, it signified that (self) inquiry and learning-based transformations were accessible in this course.

\section{Discussion}

The findings showed that ELS-31806, in particular with respect to its hands-on approach, created a sense of community, socialisation and fostered subjectification. Students were being challenged to learn together through hands-on individual experiences outside the online environment (to limit screen time) and to share these experiences afterwards with other students. Therefore, this article has dealt with two levels of development, collective and individual, that are inextricably linked to each other and the article's key concepts. Collective development, associated with sense of community, relates to the importance that all members contribute to the community's development. The individual level, is characterised by subjectification, relates to a student's freedom to be a self (Biesta, 2020) in the world.

In relation to the main question:

Q1. What might be the key elements of an online sustainability education course that fosters subjectification and creates a sense of community?

several characteristics or qualities of the learning environment enabled a sense of community at the collective level and subjectification at the individual level. The learning environments, as overarching platforms, gave students the opportunity to interact, connect and engage with one another under conditions both optimal for and essential to developing a sense of community and fostering subjectification.

A safe learning environment and the nurturing role of educators shepherded the students' sense of community. Inclusive and interactive learning was promoted by course elements at the beginning of the course through sharing personal introduction videos, breakout rooms and online discussions. These were key to promoting community building. Inclusion refers to learning together (i.e. inclusive learning) and simultaneously refers to being included in a community which increases feelings of empowerment, personal fulfilment and motivates students to reflect, feel and share emotions. Interaction invites talkativeness by actively bringing students, and educators, together in open conversation. However, a sequential order appears to be theoretically unjustified as these elements are complexly interwoven. Echoing outcomes from Burke and Larmar (2020) who argue that the educator is important in creating inclusive and safe online environments, the nurturing role of the teacher was found to be central to fostering closer relationships between student and teacher. This resulted in safe places for students to experiment, learn, collaborate and ask questions.

The principle of the nurturing teacher, incorporates other concepts such as culturally responsive teaching (Lucey et al., 2017), caring classrooms (Samuel, 2017) and pedagogies of care (Noddings, 2010; Burke and Larmar, 2020). This is embodied in the educators' supportive behaviour (e.g. being open to feedback and attentive listening to the students' needs and feelings), supporting earlier findings that a teacher's behaviour is critical to the 
IJSHE 23,8

development of online communities (Shea et al., 2002; Stone and O'Shea, 2019) . In line with Samuel (2017), this study also found that students "have to feel cared-for" (p. 76) and thus are equally responsible for the reciprocity in these relationships by actively engaging and participating in the classroom. In other words, the creating of a sense of community can be regarded as the creation of an environment co-designed through spontaneous engagement and authentic sharing between members.

Educational elements that evoked subjectification most prominently appeared in creative and reflective tasks. Being triggered to connect to themselves as central subjects, creative tasks and related creative exchanges assisted personal exploration. Amplified by course content that dealt with existential challenges vis-á-vis sustainability, students were seemingly empowered to think creatively, and form new perspectives (Loftus and Madden, 2020) around these topics:

This corresponds beautifully to Biesta's conception of subjectification (Biesta, 2010) as an individual choosing to act, to take responsibility, and for these actions to ripple out to others around them (as cited by Loftus and Madden, p. 472).

This ripple effect emerged most prominently in the emancipatory aspects of ELS-31806 and can be linked to freedom created and reinforced through individual performances, such as a modern dance. Such acts require courage, and, more importantly, a trusting environment.

\section{Limitations and future directions}

The emergent and iterative character of this research required a unique methodological approach as the study was initiated after the course was over, introducing retrospective elements (e.g. interviews) that rely on recall. These may be considered as limitations (Salkind, 2010) to the chosen approach. In addition, the rich amount of raw data took many forms (e.g. drawings, poems, short stories, etc.) which were originally reflective assignments for students rather than material to be scrutinised by researchers in search of the elements that create conditions for community and subjectification in an online learning environment. It was therefore arguably hard to interpret and decode this raw data. Even though we [the authors] were all actively involved in the preparation, execution and evaluation of ELS-31806 and our impressions were confirmed by PaCE, the more extensive analysis of the data would have benefitted from triangulation of observers. Furthermore, we have no way of ruling out bias as enrolment was noncompulsory and therefore self-selected a particular student demographic, i.e. students with a strong interest in ESE. Besides the self-selected group of students, the study was also limited to one course that was studied once.

This research arose from a focus on increased digital connectivity in education and how education can be of assistance in making people feel comfortable in online environments, especially in times when digital connectivity is rampant. Future research should give more significance to online environments in education. With the virtual space becoming increasingly important, sense of place becomes increasingly relevant. In this light, researchers should focus on place-based environmental education (Sobel, 1996; Woodhouse and Knapp, 2000) and critical pedagogies (Gruenewald, 2003) for online environments. From both collective and individual perspectives, future research might look more closely at the connection between subjectification and sense of community and socialisation and how they relate to one another.

\section{Conclusion}

In this paper, we have described a connection between the online learning environment and the role of educators and students regarding a sense of community and fostering 
subjectification. A sense of community among students grew during the four-week course. The engagement and mutual effort of students and teachers within the learning environment revealed, however, something more important. A blend, including interaction, inclusion and course elements, characterised how students and teachers co-created an environment engendering safety, a sense of community and fostering subjectification.

The creation of a sense of community occurred within the context of online sustainability education, a context inviting students to think about the complex sustainability issues of our time in which empowerment and change making are both important topics and pursued objectives. ELS-31806 gave students the opportunity to think about existential questions about life and their existence as subjects in the world they live in. By inviting these insights into Education and Sustainability Education, a whole range of online learning environments, and student-led transformations could emerge to promote a sense of community and foster subjectification. A final quote from a participant defines ELS-31806 and concurs with Biesta's educational purposes:

A suitable teaching method has a great influence on the achievements. A sense of participation, immediate adjustments, respect for everyone's emotions, honest and cutting-edge information are all elements of the success of this course (Ref.28).

\section{Notes}

1. Translated from an interview held in Dutch with Interviewee number 11.

2. A course within the Education and Learning Sciences chair group at Wageningen University \& Research (UR): https://ssc.wur.nl/Handbook/Course/ELS-31806

3. Taking pictures in the direct surroundings of the students' homes and labelling the images as "sustainable" or "unsustainable".

4. Note that Braun and Clarke (2006) provide an exact and sequential step-by-step guide for thematic analysis. In this research these steps (i.e., phases) were less consecutive and structured, but emerged 'en route'.

\section{References}

Balboni, G., Perrucci, V., Cacciamani, S. and Zumbo, B.D. (2018), "Development of a scale of sense of community in university online courses", Distance Education, Vol. 39 No. 3, pp. 317-333, doi: 10.1080/01587919.2018.1476843.

Berge, Z.L. (1995), "Facilitating computer conferencing: recommendations from the field", Educational Technology, Vol. 15 No. 1, pp. 22-30, available at: www.emoderators.com/moderators/ teach_online.html (accessed 14 January 2022).

Besser, H., Donahue, S. (1996), "Introduction and overview: perspectives on [. . . ] distance independent education", Journal of the American Society for Information Science, Vol. 47 No. 11, pp. 801-804.

Biesta, G. (2020), "Risking ourselves in education: qualification, socialization, and subjectification revisited", Educational Theory, Vol. 70 No. 1, pp. 89-104, doi: 10.1111/edth.12411.

Biesta, G.J. (2010), Good Education in an Age of Measurement Ethics, Politics, Democracy, Routledge, Taylor and Francis Group, London.

Braun, V. and Clarke, V. (2006), "Using thematic analysis in psychology", Qualitative Research in Psychology, Vol. 3 No. 2, pp. 77-101.

Brown, R. (2001), "The process of community building in distance learning classes", Journal of Asynchronous Learning Networks, Vol. 5 No. 2, pp. 18-35. 
IJSHE 23,8

Brundiers, K., Barth, M., Cebrián, G., Cohen, M., Diaz, L., Doucette-Remington, S., Dripps, W., Habron, G., Harré, N., Jarchow, M. and Losch, K. (2021), "Key competencies in sustainability in higher education - toward an agreed-upon reference framework", Sustainability Science, Vol. 16 No. 1, pp. 13-29, doi: 10.1007/s11625-020-00838-2.

Burke, K. and Larmar, S. (2020), "Acknowledging another face in the virtual crowd: reimagining the online experience in higher education through an online pedagogy of care", Journal of Further and Higher Education, Vol. 45 No. 5, pp. 601-615, doi: 10.1080/0309877X.2020.1804536.

Eernstman, N. and Wals, A. (2013), "Locative meaning-making: an arts-based approach to learning for sustainable development”, Sustainability, Vol. 5 No. 4, pp. 1645-1660, doi: 10.3390/su5041645.

Ellis, W.E., Dumas, T.M. and Forbes, L.M. (2020), "Physically isolated but socially connected: psychological adjustment and stress among adolescents during the initial COVID-19 crisis", Canadian Journal of Behavioural Science/Revue Canadienne Des Sciences du Comportement, Vol. 52 No. 3, pp. 177-187, doi: 10.1037/cbs0000215.

Graham, M. and Scarborough, H. (2001), "Enhancing the learning environment for distance education students", Distance Education, Vol. 22 No. 2, pp. 232-244, doi: 10.1080/0158791010220204.

Gruenewald, D.A. (2003), "The best of both worlds: a critical pedagogy of place", Educational Researcher, Vol. 32 No. 4, pp. 3-12.

Hare, A.P. and Davis, M.F. (1994), "Social interaction”, in Hare, A.P., Blumberg, H.H., Davies, M.F. and Kent, M.V. (Eds), Small Group Research: A Handbook, Ablex, Norwood, NJ, pp. 169-193.

Hasslöf, H. and Malmberg, C. (2015), "Critical thinking as room for subjectification in education for sustainable development”, Environmental Education Research, Vol. 21 No. 2, pp. 239-255, doi: 10.1080/13504622.2014.940854.

Hu, P.J. and Hui, W. (2012), "Examining the role of learning engagement in technology-mediated learning and its effects on learning effectiveness and satisfaction", Decision Support Systems, Vol. 53 No. 4, pp. 782-792, doi: 10.1016/j.dss.2012.05.014.

Jung, I., Choi, S., Lim, C. and Leem, J. (2002), "Effects of different types of interaction on learning achievement, satisfaction and participation in web-based instruction", Innovations in Education and Teaching International, Vol. 39 No. 2, pp. 153-162, doi: 10.1080/14703290252934603.

Kerka, S. (1996), "Distance learning, the internet, and the world wide web", ERIC Digest, ERIC Document Reproduction Service No. ED 395214.

Kipnis, A.B. (2011), "Subjectification and education for quality in China", Economy and Society, Vol. 40 No. 2, pp. 289-306, doi: 10.1080/03085147.2011.548950.

Lange, E.A. (2009), "Fostering a learning sanctuary for transformation in sustainability education", in Mezirow, J. and Taylor, E.W. (Eds), Transformative Learning in Practice: Insights from Community, Workplace, and Higher Education, Jossey-Bass, San Francisco, CA.

Linnenbrink, E.A. (2006), "Emotion research in education: theoretical and methodological perspectives on the integration of affect, motivation, and cognition”, Educational Psychology Review, Vol. 18 No. 4, pp. 307-314, doi: 10.1007/s10648-006-9028-x.

Liu, X. and Schwen, T.M. (2008), "Sociocultural factors affecting the success of an online MBA course", Performance Improvement Quarterly, Vol. 19 No. 2, pp. 69-92.

Liu, X., Magjuka, R.J., Bonk, C.J. and Lee, S.-H. (2007), "Does sense of community matter? An examination of participants' perceptions of building learning communities in online courses", The Quarterly Review of Distance Education, Vol. 8 No. 1, pp. 9-24.

Loftus, M. and Madden, M.G. (2020), "A pedagogy of data and artificial intelligence for student subjectification”, Teaching in Higher Education, Vol. 25 No. 4, pp. 456-475, doi: 10.1080/ 13562517.2020.1748593.

Lucey, T.A., White, E.S. and Stephen, L. (2017), "Mentorship in higher education: compassionate approaches supporting culturally responsive pedagogy", Multicultural Education, Vol. 24 No. 2, pp. 11-17. 
McMillan, D.W. (1996), “Sense of community”, Journal of Community Psychology, Vol. 24 No. 4, pp. 315-325.

Noddings, N. (2010), "Moral education and caring", Theory and Research in Education, Vol. 8 No. 2, pp. 145-151, doi: 10.1177/1477878510368617.

O'Sullivan, E. (1999), Transformative Learning: Educational Vision for the 21st Century, Zed Books, London.

Creating a sense of community and space

Perna, L.W., Ruby, A., Boruch, R.F., Wang, N., Scull, J., Ahmad, S. and Evans, C. (2014), "Moving through MOOCs", Educational Researcher, Vol. 43 No. 9, pp. 421-432, doi: 10.3102/ 0013189x14562423.

Rice-Lively, M.L. (1994), "Wired warp and woof: an ethnographic study of a networking class", Internet Research, Vol. 4 No. 4, pp. 20-35.

Rovai, A.P. (2002a), "Building sense of community at a distance", The International Review of Research in Open and Distributed Learning, Vol. 3 No. 1, pp. 1-16, doi: 10.19173/irrodl.v3i1.79.

Rovai, A.P. (2002b), "Sense of community, perceived cognitive learning, and persistence in asynchronous learning networks", The Internet and Higher Education, Vol. 5 No. 4, pp. 319-332.

Salkind, N.J. (2010), Encyclopedia of Research Design, SAGE Publications, Thousand Oaks, CA.

Samuel, K. (2017), "Creating more caring university classrooms”, In Brookings (2017), Meaningful Education in Times of Uncertainty: Collection of Essays, Brookings, pp. 75-83.

Shea, P., Li, C.S., Swan, K. and Pickett, A. (2002), "Developing learning community in online asynchronous college courses: the role of teaching presence", Journal of Asynchronous Learning Networks, Vol. 9 No. 4, pp. 59-82.

Sobel, D. (1996), Beyond Ecophobia: Reclaiming the Heart in Nature Education, The Orion Society and The Myrin Institute, Great Barrington, MA.

Stone, C. and O'Shea, S. (2019), "Older, online and first: recommendations for retention and success”, Australasian Journal of Educational Technology, Vol. 35 No. 1, pp. 57-69, doi: 10.14742/ajet.3913.

UNESCO. (2020), "Education: from disruption to recovery", UNESCO, available at: https:/en.unesco. org/covid19/educationresponse

Van der Meer, S.V. and Wals, A.E. (2017), "Leren voor Duurzame Ontwikkeling, een Verkenning van een Learnscape: Gebaseerd op interviews met uiteenlopende experts op het gebied van leren voor duurzame ontwikkeling”, doi: 10.18174/406796.

Wageningen University and Research. (2020), “Annual report 2019”, Wageningen University and Research, Wageningen.

Wals, A.E., Geerling-Eijff, F., Hubeek, F., van der Kroon, S. and Vader, J. (2008), "All mixed up? Instrumental and emancipatory learning toward a more sustainable world: considerations for EE policymakers", Applied Environmental Education and Communication, Vol. 7 No. 3, pp. 55-65.

Weidlich, J. and Bastiaens, T.J. (2019), "Designing sociable online learning environments and enhancing social presence: an affordance enrichment approach", Computers and Education, Vol. 142, p. 103622, doi: 10.1016/j.compedu.2019.103622.

Woodhouse, J. and Knapp, C. (2000), "Place-based curriculum and instruction", (ERIC Document Reproduction Service No. EDO-RC-00-6.).

World Economic Forum. (2020), "The COVID-19 pandemic has changed education forever", This is how, available at: www.weforum.org/agenda/2020/04/coronavirus-education-global-covid19online-digital-learning/

Zhao, L., Lu, Y., Wang, B., Chau, P.Y. and Zhang, L. (2012), "Cultivating the sense of belonging and motivating user participation in virtual communities: a social capital perspective", International Journal of Information Management, Vol. 32 No. 6, pp. 574-588, doi: 10.1016/j.ijinfomgt.2012.02.006. 
IJSHE

23,8

104

\section{About the authors}

Robbert Hesen is a Junior Project Officer at IVN (The Dutch Institute for Nature Education and Sustainability) and Freelance Researcher at Wageningen UR. His work focuses on "Nature and Children" through hands-on educational approaches for more sustainable and nature-inclusive futures.

Arjen E.J. Wals is a Professor of Socio-Ecological Sustainability at Wageningen University where he also holds the UNESCO Chair of Social Learning and Sustainable Development. Furthermore, he is a Guest Professor at the Norwegian University for the Life Sciences and holds an Honorary Doctorate from Gothenburg University in Sweden. Arjen E.J. Wals is the corresponding author and can be contacted at: Arjen.wals@wur.nl

Rebekah L. Tauritz is a Postdoc researcher and teacher in environmental and sustainability education at Wageningen University. She sees herself as a co-explorer and critical friend to educators looking for the best way to prepare their learners for dealing with an increasingly complex and unknown future.

For instructions on how to order reprints of this article, please visit our website: www.emeraldgrouppublishing.com/licensing/reprints.htm Or contact us for further details: permissions@emeraldinsight.com 